\title{
FLEXURAL BEHAVIOR OF LAPPED SPLICED HIGH STRENGTH R.C BEAMS SUBJECTED TO STATIC LOADING
}

\author{
Eng. Hatem A. Mahmoud \\ Expert Engineer in Ministry of Justice, Aswan, Egypt \\ tommyeg2@yahoo.com
}

\author{
Yehia A. Hassanean and Abdelrahman Megahid \\ Civil Engineering Department, Faculty of Engineering, Assiut University, \\ Assiut, Egypt \\ yehiamk@yahoo.com
}

(Received January 25, 2006 Accepted February 18, 2006)

\begin{abstract}
An experimental program was formulated to investigate the influence of some factors affected the overall flexural behaviour of high strength under reinforced concrete beams lapped at tension zone. Fourteen beams were made from high strength concrete and only one beam made from normal strength concrete. These beams were tested under two point static loading to study the flexural behaviour of high strength concrete beams reinforced with spliced tension bars. The effect of concrete compressive strength, lap splice length, transverse reinforcement at lap splice and the percentage of tension reinforcement ratio on its behaviour were considered. Also, the experimental results were compared with those predicted values based on the available well-known theoretical equations. The tests showed that the increase of concrete compressive strength, transverse reinforcement at lap splice regions and lap splice length considerably improve the flexural behaviour of high strength under reinforced concrete beams.
\end{abstract}

KEYWORDS: High Strength Concrete, Flexural Behaviour, Lap Splice Length.

\section{INTRODUCTION}

Since the mid of 1980s, high strength concrete, (HSC), has gained popularity for diverse application such as bridges, tall building, off- shore structures pavement, etc. Research data are needed on the effects of using HSC on all relevant structural behavior to ensure that there are no detrimental effects. Despite the necessity of test data of HSC, the knowledge of bond strength has been advanced to certain level.

Comprehensive studies [1 to 3] in 1977 showed that confinement, resulting from both concrete and transverse reinforcement enveloping the main reinforcement to resist splitting, can improve bond resistance. Rezansoff et al. [4], in 1993 indicated that the heavier stirrup confinement beyond the current limit is still effective. 
Shyh et al. [5] in 1996, tested twenty beams to investigate the tensile bond strength of deformed bars embedded in HSC, $\left(f_{\mathrm{c}}^{\prime} \leq 70 \mathrm{MPa}\right)$. They concluded that for HSC the equivalence between the tensile development length and splice length was established and confinement beyond the currently accepted limit was still effective for bond action. With or without stirrups tension bar development or splicing is usually limited by splitting strength of the surrounding concrete; and stirrups across potential longitudinal splitting crack slow the progressive of splitting and restrain such crack widths after they start. Splitting is caused by inclined compression forces acting between bar lugs and surrounding concrete, [6].

Based on a statistical examination of test result, Orangun et al. [1] in 1977, derived an empirical equation of bond strength to account for the effects of concrete compressive strength, concrete cover, bar size, bar spacing, development length and transverse reinforcement. They examined 254 development length tests and 286 splices tests reported in literature in which failure occurred in bond before yielding of the bar. A single empirical equation was derived from nonlinear regression analysis of test results that is equally applicable to both lap splices and development lengths as follows:

$$
U_{O J B}=\left(0.10+0.25 \frac{\mathrm{c}}{\mathrm{d}_{\mathrm{b}}}+4.15 \frac{\mathrm{d}_{\mathrm{b}}}{\mathrm{L}}+\frac{\mathrm{A}_{\mathrm{tr}} f_{y t}}{41.25 s d_{b}}\right) \sqrt{f_{c}^{\prime}}
$$

Where:

$\mathrm{U}_{\mathrm{OJB}}$ the calculated bond strength in MPa;

c the minimum of clear concrete cover and half-clear spacing between bars in $\mathrm{mm}$;

$\mathrm{A}_{\text {tr }}$ the area of transverse reinforcement crossing the critical splitting cracks beside the anchored bar, in $\mathrm{mm}^{2}$;

$f_{\mathrm{yt}} \quad$ the yield stress of the transverse steel in $\mathrm{MPa}$;

$\mathrm{s} \quad$ spacing of transverse reinforcement in $\mathrm{mm}$;

$f_{\mathrm{c}}^{\prime} \quad$ cylindrical concrete compressive strength in $\mathrm{MPa}$;

$\mathrm{L} \quad$ splice or developed length in $\mathrm{mm}$ and;

$\mathrm{d}_{\mathrm{b}} \quad$ diameter of spliced bar in $\mathrm{mm}$.

Two respective are placed for equation (1) as follows:

$$
\frac{c}{d_{b}} \leq 2.50 \quad \text { and } \quad \frac{\mathrm{A}_{\mathrm{tr}} f_{y t}}{41.25 s d_{b}} \leq 0.25
$$

Also, The bond strength implied by ACI Subcommittee 318-B [7] is:

$$
U_{318-B}=0.276 \frac{k^{\prime} \sqrt{f_{c}^{\prime}}}{d_{b}}
$$

Where:

- $\mathrm{k}^{\prime}$ is smallest of $\mathrm{C}_{\mathrm{c}}+\mathrm{k}_{\mathrm{tr}}{ }^{\prime}$ or $\mathrm{C}_{\mathrm{s}}^{\prime}+\mathrm{k}_{\mathrm{tr}}{ }^{\prime}$ or $2.5 \mathrm{~d}_{\mathrm{b}}$;

- $\mathrm{C}_{\mathrm{c}}$ one-half the bar diameter plus the clear cover measured from the extreme tension fiber to the edge of the bar being spliced in $\mathrm{mm}$;

- $\mathrm{C}_{\mathrm{s}}^{\prime}$ for splices is the smaller of the side cover to the center of the outside bar or one half of the smaller center to center distance of the bars coming from direction and spliced at the same section in $\mathrm{mm}$; and; 
- $k_{t r}^{\prime}=\frac{A_{t r}^{\prime} f_{y t}}{10.5 s N} \leq 2 d_{b}$, where, $\mathrm{N}$, is the number of developing bars confined by $\mathrm{A}_{\mathrm{tr}}^{\prime}$ for splitting crack pattern.

Hosny et-al; [8] discussed the mechanism of bond failure and influence of splitting is emphasized. They presented a comparison between different national building codes for development length $\mathrm{L}_{\mathrm{d}}$, of tension reinforcement using deformed bar of $25 \mathrm{~mm}$ diameter of $370 \mathrm{MPa}$ yield strength and concrete of compressive strength $27.5 \mathrm{MPa}$. They concluded that there is a large difference between these national building codes. The biggest development length was equal to 70 times bar diameter. ECCS 203 [9], estimates the development length, $\left(\mathrm{L}_{\mathrm{d}}\right)$ by:

$$
L_{d}=\frac{\Phi \alpha \beta \eta \frac{f_{y}}{\gamma_{s}}}{4 f_{b u}}
$$

Where:

$\Phi \quad$ Nominal bar diameter;

$\alpha$ Correction factor depends on shape of bar ends;

$\beta$ Correction factor depends on type of bar surface;

$\eta \quad 1.30$ for top reinforcement with concrete below it more than $300 \mathrm{~mm}$ thickness,

$\eta \quad 1.0$ for other cases and;

$f_{\text {bu }}$ the design value of bond strength in $\mathrm{N} / \mathrm{mm}^{2}$ and estimated by:

$$
f_{b u}=0.30 \sqrt{\frac{f_{c u}}{\gamma_{c}}}
$$

Where $\gamma_{\mathrm{c}}$ is a material factor and $f_{c u}$ is the cube compressive strength in $\mathrm{N} / \mathrm{mm}^{2}$. Also, the British code BS8110/1985, sited from [10], estimates the design value of bond stress $f_{\text {bu }}$ as follows:

$$
f_{b u}=\beta \sqrt{f_{c}}
$$

Where $\beta$ is a bond coefficient depending on the bar type and $f_{\mathrm{c}}$ is the cube compressive strength of the concrete.

Lacking of the experimental results of HSC, the ACI code [11], places an arbitrarily upper limit of $70 \mathrm{MPa}$ on the assumed compressive strength of concrete for determination of anchorage lengths. Therefore, experimental data on the bond are needed to affirm capabilities and to fully use the advantage of HSC.

A review of test literature shows that the principal influences on tension splices strength to be concrete strength, splice length, concrete cover to spliced bars and the amount of transverse reinforcement around the lapped bars.

The main objective of this work is to describe the overall behavior of HSC beams reinforced with tension bars spliced at zone of maximum bending moment taking into consideration the effect of compressive strength of the used concrete, lap splice length, transverse reinforcement at lap splice, (confinement ratio), and percentage of tension reinforcement. The concrete cover was taken as considered in ECCS 203, [9]. Some of the tested beams were specially designed to fail due to bond failure. 


\section{MATERIALS}

Concrete mixes were designed to produce concrete having a 28 days cubic compressive strength of 27.5, 70.0, 80.0 and $90.0 \mathrm{MPa}$. The mixes proportions by weight are presented in Table 1. The constituent materials were:

a) Ordinary Portland cement, its properties are confirmed with limits of ECCS 203, [9].

b) Local sand of $2.60,1.58 \mathrm{t} / \mathrm{m}^{3}$ and 2.58 specific gravity, volume weight and fineness modules respectively.

c) Local gravel of $20 \mathrm{~mm}$ maximum nominal size, 2.65 specific gravity and $1.61 \mathrm{t} / \mathrm{m}^{3}$ volume weight was used in NSC. Crushed basalt of two sizes one of them was 20 $\mathrm{mm}$ maximum nominal size and the other was $10 \mathrm{~mm}$ maximum nominal size was used in HSC. The crushed basalt has 2.70 specific gravity and $2.35 \mathrm{t} / \mathrm{m}^{3}$ volume weight.

d) Drinking water was used for both mixing and curing.

e) Superplasticizer; was used.

f) Silica fume of average particle size $0.1 \mu \mathrm{m}$, specific surface area $\left(12-15 \mathrm{~m}^{2} / \mathrm{g}\right)$ and specific gravity 2.20 .

g) Reinforcing steel bars with different diameters and grades confirms with the limits of ESC 203, were used. The mechanical properties of the used steel are presented in Table 2, [9].

Table 1: Mix proportions by weight for the different mixes.

\begin{tabular}{|c|c|c|c|c|c|c|c|c|c|}
\hline \multirow{4}{*}{$\begin{array}{l}\text { Mix } \\
\text { No. }\end{array}$} & \multicolumn{8}{|c|}{ Amount of constituent materials $/ \mathrm{m}^{3}$} & \multirow{4}{*}{$\begin{array}{r}F_{c} \\
M P a\end{array}$} \\
\hline & \multirow{3}{*}{$\begin{array}{c}\text { Cement } \\
\text { (kg) }\end{array}$} & \multirow{3}{*}{$\begin{array}{l}\text { Sand } \\
\text { (kg) }\end{array}$} & \multicolumn{3}{|c|}{ Coarse aggregate (kg) } & \multirow{3}{*}{$\begin{array}{l}\text { Water } \\
\text { (liter) }\end{array}$} & \multirow{3}{*}{$\begin{array}{l}\text { Silica } \\
\text { fume } \\
\text { (Liter) }\end{array}$} & \multirow{3}{*}{$\begin{array}{l}\text { Add. } \\
\text { (kg) }\end{array}$} & \\
\hline & & & \multirow[t]{2}{*}{ Gravel } & \multicolumn{2}{|c|}{ Crushed Basalt } & & & & \\
\hline & & & & Basalt 1 & Basalt 2 & & & & \\
\hline 1 & 500 & 600 & - & 610 & 610 & 140 & 100 & 15 & 92.1 \\
\hline 2 & 475 & 584 & - & 594 & 594 & 142.5 & 71.15 & 9.5 & 81.2 \\
\hline 3 & 450 & 591 & - & 600 & 600 & 144 & 67.5 & 6.75 & 72.4 \\
\hline 4 & 350 & 618 & 1237 & - & - & 192.5 & & - & 27.9 \\
\hline
\end{tabular}

Table 2: Mechanical properties of the used steel

\begin{tabular}{|l|c|c|c|c|c|c|}
\hline Commercial diameter $(\mathbf{m m})$ & 6 & 10 & 16 & 18 & 22 & 24 \\
\hline Actual diameter $(\mathbf{m m})$ & 6.01 & 9.94 & 15.76 & 17.89 & 21.84 & 23.95 \\
\hline Yield stress $\mathbf{( M P a )}$ & 253.8 & 388.4 & 390.9 & 444.7 & 420.9 & 429.2 \\
\hline Ultimate stress $\mathbf{( M P a )}$ & 373.5 & 598.0 & 611.2 & 723.8 & 676.3 & 691.5 \\
\hline \% of elongation & 25.3 & 24.2 & 22.6 & 19.4 & 20.8 & 19.7 \\
\hline
\end{tabular}




\section{TEST PROGRAM, FABRICATION OF THE TESTED BEAMS AND TEST PROCEDURE}

This program was carried out in reinforced concrete laboratory, Assiut University. Through this program, fifteen reinforced concrete beams were tested. Fourteen beams were made from HSC and the other beam was made from NSC. All tested beams having $20 \times 30 \mathrm{~cm}$ rectangular cross-section and $230 \mathrm{~cm}$ total length. Beams were tested under two-point static loading with constant span to depth ratio $(\mathrm{a} / \mathrm{d}=3.0)$. The tested beams were reinforced with two bars $10 \mathrm{~mm}$ diameter as compression reinforcement and stirrups $6 \mathrm{~mm}$ diameter with $15 \mathrm{~cm}$ spacing. The concrete cover is taking as recommended in ECCS 203, [9], in all tested beams. The main variables taken into consideration were compressive strength of the used concrete $f_{c}$, lap splice length $\left(\mathrm{L}_{\mathrm{d}}\right)$, area of transverse reinforcement $\mathrm{A}_{\text {tr }}$ at lap splice region and percentage of tension reinforcement $(\mu)$. Complete details of all tested beams are presented in Table $\mathbf{3}$, and Fig. 1 shows details of beams having 60Ф splice length.

Table 3: Details of tested beams.

\begin{tabular}{|c|c|c|c|c|c|}
\hline $\begin{array}{c}\text { Beam } \\
\text { No. }\end{array}$ & $\begin{array}{c}\text { Tension } \\
\text { reinforcement }\end{array}$ & $\begin{array}{c}\mu \\
\%\end{array}$ & $\begin{array}{c}\boldsymbol{f}_{\boldsymbol{c}} \\
(\mathbf{M P a})\end{array}$ & $\mathbf{L}_{\mathbf{s}}$ & $\begin{array}{c}\text { Stirrups at } \\
\text { splice region }\end{array}$ \\
\hline $\mathrm{B}_{1}$ & $2 \Phi 18$ & 0.958 & 27.9 & $60 \Phi$ & $\phi 6 / 15 \mathrm{~cm}$ \\
\hline $\mathrm{B}_{2}$ & $2 \Phi 18$ & 0.958 & 72.4 & $60 \Phi$ & $\phi 6 / 15 \mathrm{~cm}$ \\
\hline $\mathrm{B}_{3}$ & $2 \Phi 18$ & 0.958 & 81.2 & $60 \Phi$ & $\phi 6 / 15 \mathrm{~cm}$ \\
\hline $\mathrm{B}_{4}$ & $2 \Phi 18$ & 0.958 & 92.1 & $60 \Phi$ & $\phi 6 / 15 \mathrm{~cm}$ \\
\hline $\mathrm{B}_{11}$ & $2 \Phi 18$ & 0.958 & 92.1 & - & $\phi 6 / 15 \mathrm{~cm}$ \\
\hline $\mathrm{B}_{12}$ & $2 \Phi 18$ & 0.958 & 92.1 & $10 \Phi$ & $\phi 6 / 15 \mathrm{~cm}$ \\
\hline $\mathrm{B}_{13}$ & $2 \Phi 18$ & 0.958 & 92.1 & $20 \Phi$ & $\phi 6 / 15 \mathrm{~cm}$ \\
\hline $\mathrm{B}_{14}$ & $2 \Phi 18$ & 0.958 & 92.1 & $30 \Phi$ & $\phi 6 / 15 \mathrm{~cm}$ \\
\hline $\mathrm{B}_{15}$ & $2 \Phi 18$ & 0.958 & 92.1 & $40 \Phi$ & $\phi 6 / 15 \mathrm{~cm}$ \\
\hline $\mathrm{B}_{16}$ & $2 \Phi 18$ & 0.958 & 92.1 & $50 \Phi$ & $\phi 6 / 15 \mathrm{~cm}$ \\
\hline $\mathrm{B}_{19}$ & $2 \Phi 18$ & 0.958 & 92.1 & $30 \Phi$ & $\phi 6 / 5 \mathrm{~cm}$ \\
\hline $\mathrm{B}_{20}$ & $2 \Phi 18$ & 0.958 & 92.1 & $30 \Phi$ & $\phi 6 / 10 \mathrm{~cm}$ \\
\hline $\mathrm{B}_{24}$ & $2 \Phi 16$ & 0.756 & 92.1 & $60 \Phi$ & $\phi 6 / 15 \mathrm{~cm}$ \\
\hline $\mathrm{B}_{25}$ & $2 \Phi 22$ & 1.445 & 92.1 & $60 \Phi$ & $\phi 6 / 15 \mathrm{~cm}$ \\
\hline $\mathrm{B}_{26}$ & $2 \Phi 24$ & 1.727 & 92.1 & $60 \Phi$ & $\phi 6 / 15 \mathrm{~cm}$ \\
\hline
\end{tabular}

Where:

$\mu \quad$ Percentage of main steel reinforcement,

$\mathrm{L}_{\mathrm{d}} \quad$ Lap splices length,

$f_{\mathrm{c}} \quad$ Cube concrete compressive strength, average value of three cubes.

Mechanical mixing is used for all tested beams. All beams were cast in steel forms and using mechanical internal rod vibrator in the compaction. Control cube specimens were cast from each mix. The method of compaction and curing was performed in the same manner as that for beams. The beams were loaded under two-point static loading on increments. Before cracking each increment was 0.50 ton and after cracking each 
increment was 1.0 ton. The load was kept constant between two successive increments for about five minutes. During this period, reading of both strain gauges and dial gauges are recorded and the crack propagation was observed at both beginning and end of each increment of loading. At the same time, three control cubes were tested in compression. The beam maximum deflection was measured using dial gauge fixed at mid span as well as the embedded slip is measured through a recess of $50 \mathrm{~mm}$ length exposed the spliced bar below the concentrated load. Also, the free end slip is measured at the free end of the reinforced bars. For all tested beams the strain in concrete was measured at mid span at compression zone and strain in steel was measured in tension reinforcement. At the end of each test the crack pattern was traced and noticed.

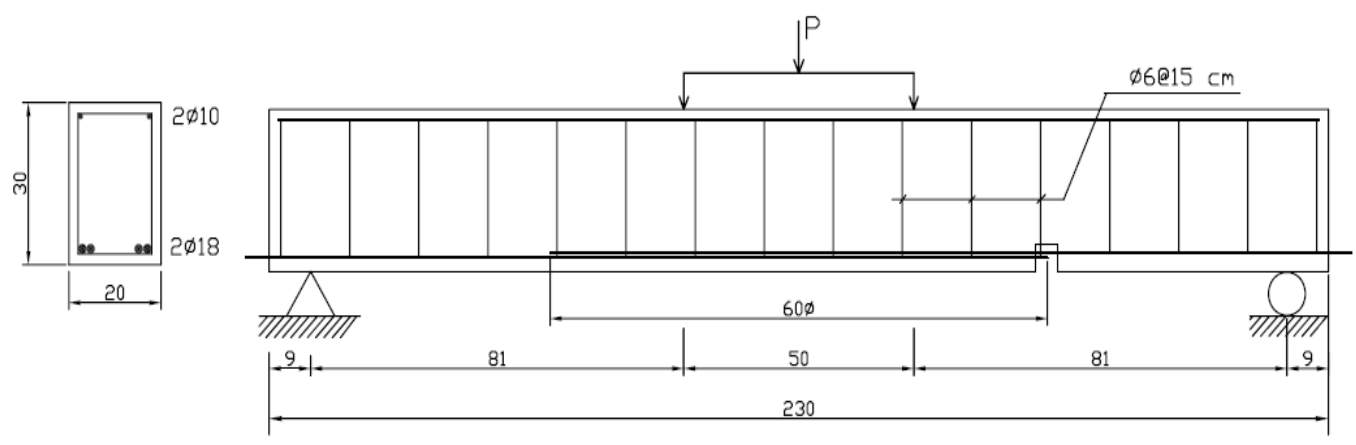

Fig. 1: Details of Beams $B_{1}, B_{2}, B_{3}$ and $B_{4}$.

\section{TEST RESULTS AND DISCUSSION}

Examination of the test results given in Tables $\mathbf{4}$ and $\mathbf{5}$ as well as that plotted in Figs. 2 to 5 declares the following:

\section{PATTERN OF CRACKS AND MODES OF FAILURE}

Flexural cracks were observed in the region of pure bending moment for all tested beams. In beams made from NSC, a horizontal crack appeared in the region from the end of lap splice of the bars to the support, to be a sign of bond cracks. The beams that reinforced with bars having 60Ф lap splice length and made from HSC were failed due to diagonal tension crack denoted by shear compression failure.

The pattern of crack and mode of failure is affected by the lap splice length. A sudden failure was occurred in beam $B_{12}$ that reinforced with bars have $10 \Phi$ lap splice length, a complete rapture is happened at the end of the splice and the beam is separated in two parts like failure of plain concrete beams. For beam $\left(B_{13}\right)$, that having $20 \Phi$ lap splice length, vertical cracks at zone of pure bending moment were formed, causing the beam take failed with flexural bond mode failure. In beams that having lap splice length higher than 30Ф, few flexural cracks were formed in the zone of lap splice from early stages of loading up to failure. The modes of failure of these beams were diagonal tension failure as beams have $60 \Phi$ lap splice lengths and beam $B_{11}$ without splices. Increasing area of transverse reinforcement $\left(\mathrm{A}_{\mathrm{tr}}\right)$ at splices, change the pattern of crack and the mode of failure to be flexural failure mode, see Fig. 2.k. 
In beam $\mathrm{B}_{24}$ that having $0.756 \%$ of tension reinforcement the failure was due to vertical crack formed at the end of the splice. This may be due to the mid span cross section having double area of steel reinforcement, so the section was stiffer than the section at the end of splice since the failure occurs at end of the splice that is the weakest section.

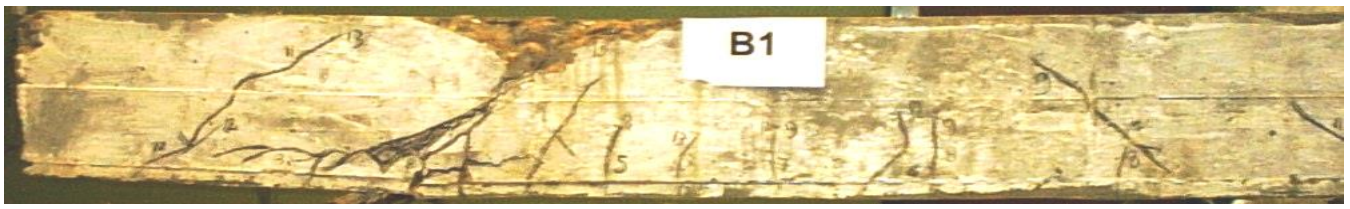

Fig. 2.a: Pattern of crack of the tested beam (B1).

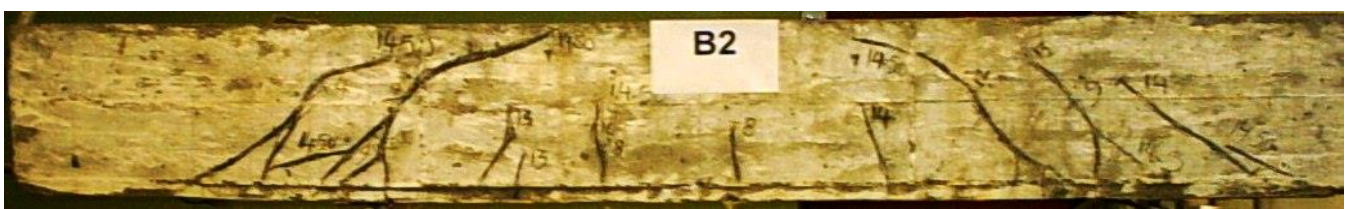

Fig. 2.b: Pattern of crack of the tested beam (B2).

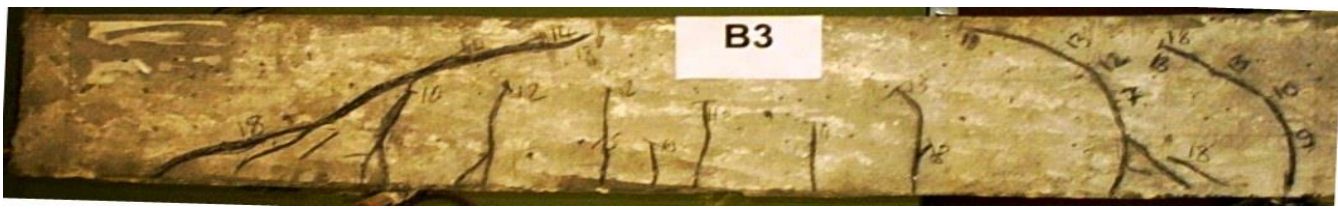

Fig. 2.c: Pattern of crack of the tested beam (B3).

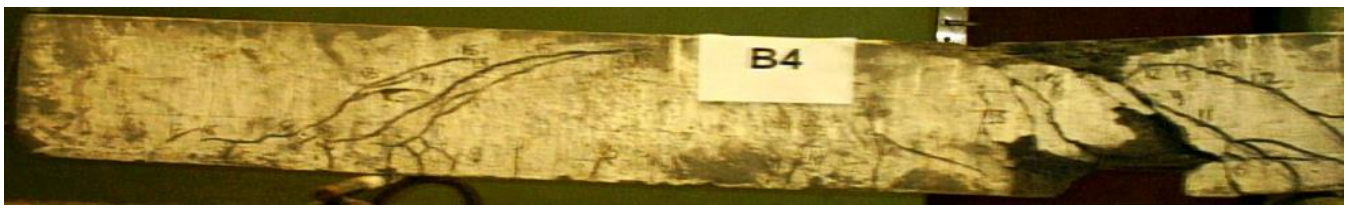

Fig. 2.d: Pattern of crack of the tested beam (B4).

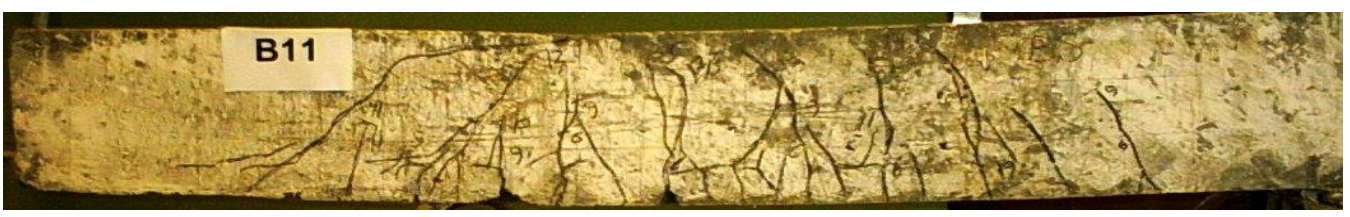

Fig. 2.e: Pattern of crack of the tested beam (B11).

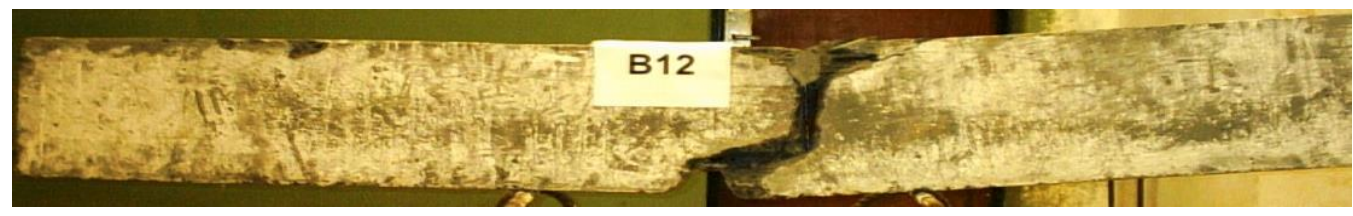

Fig. 2.f: Pattern of crack of the tested beam (B12). 


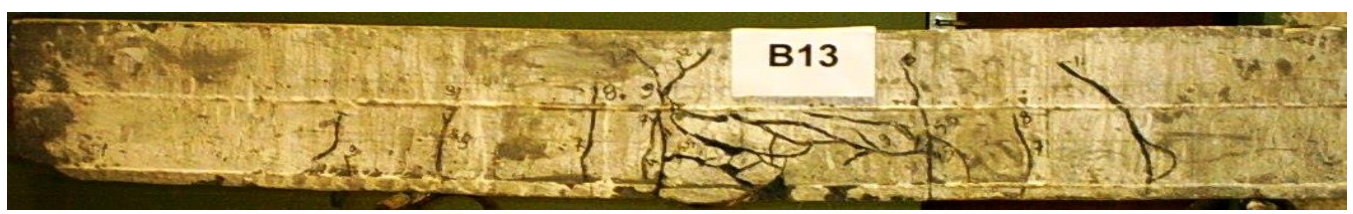

Fig. 2.g: Pattern of crack of the tested beam (B13).

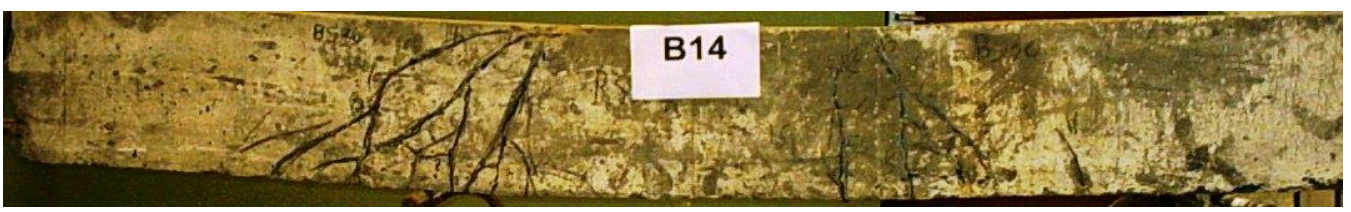

Fig. 2.h: Pattern of crack of the tested beam (B14).

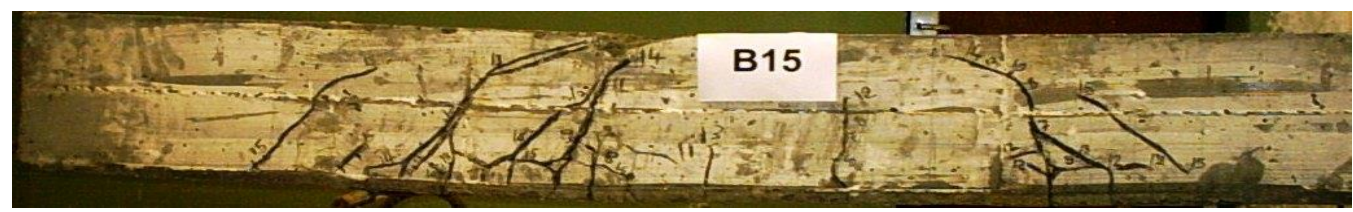

Fig. 2.i: Pattern of crack of the tested beam (B15).

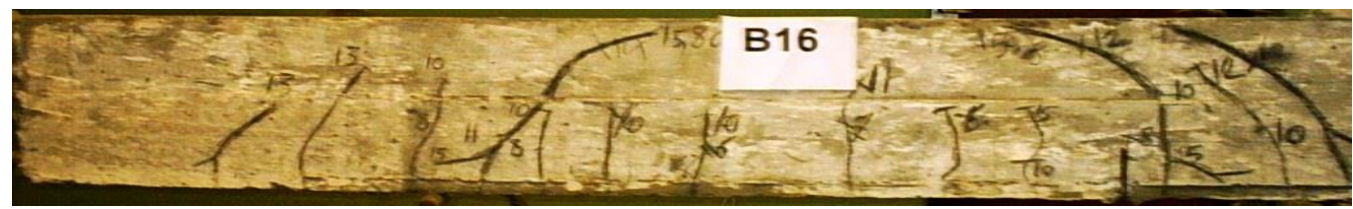

Fig. 2.j: Pattern of crack of the tested beam (B16).

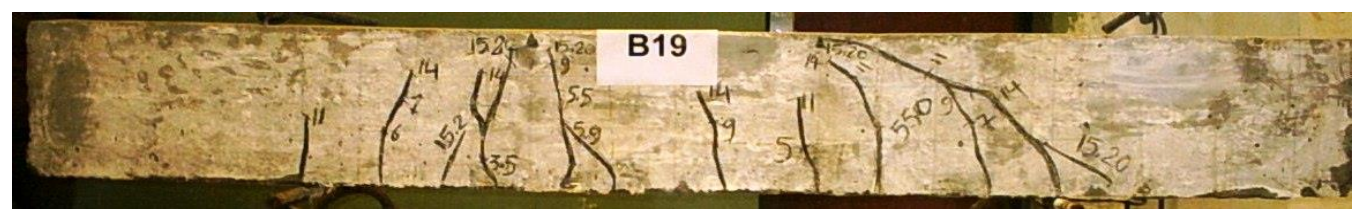

Fig. 2.k: Pattern of crack of the tested beam (B19).

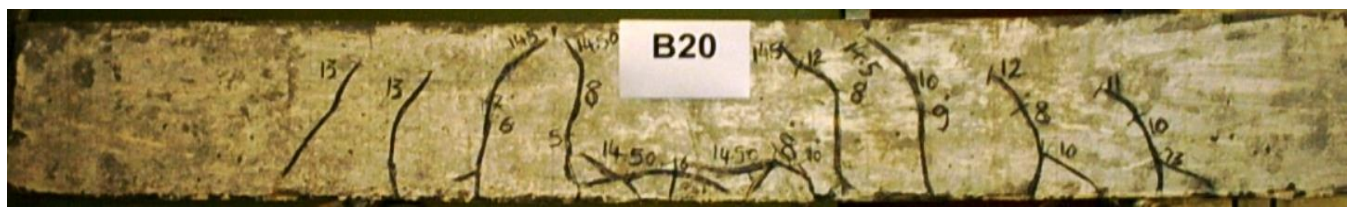

Fig. 2.L: Pattern of crack of the tested beam (B20).

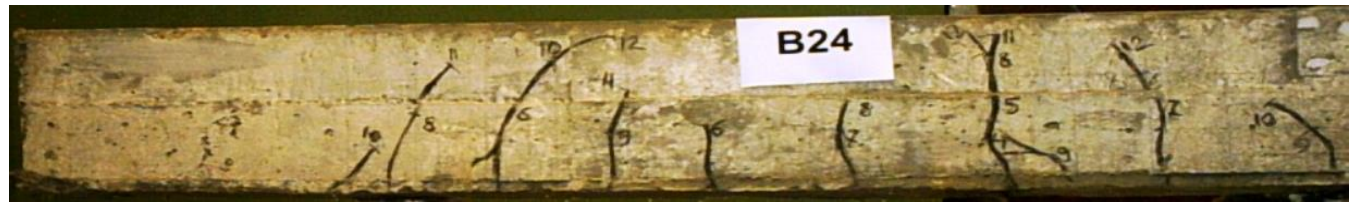

Fig. 2.m: Pattern of crack of the tested beam (B24). 


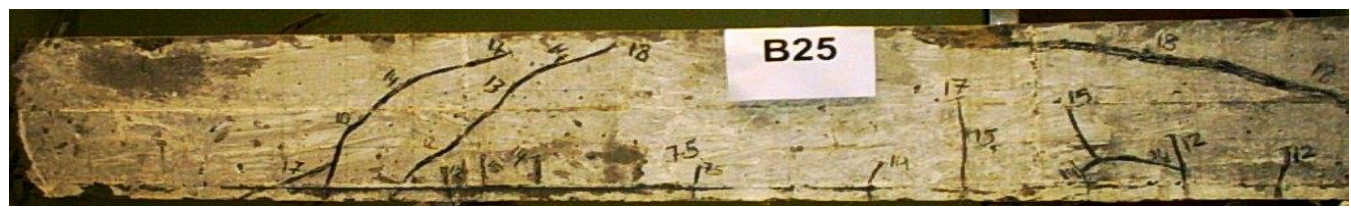

Fig. 2.n: Pattern of crack of the tested beam (B25).

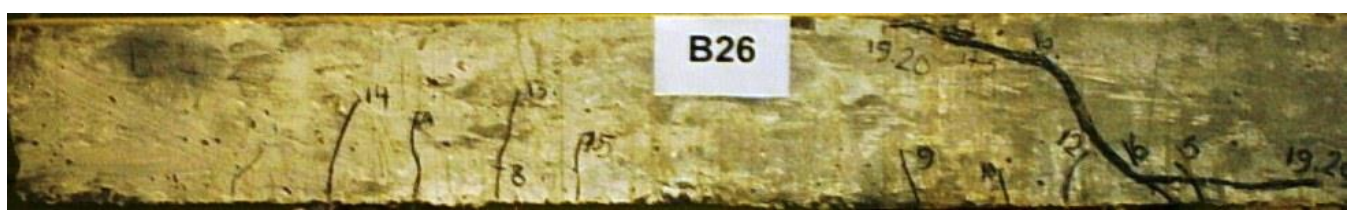

Fig. 2.0: Pattern of crack of the tested beam (B26).

\section{CRACKING AND ULTIMATE LOADS}

From investigation of Table 4 and Figs. 3.a to 3.d, it is obvious that:

The concrete compressive strength has a pronounce effect on the cracking load, the cracking load increases as the concrete compressive strength increases. This is due to the increase of the tensile strength of concrete which is proportional to its compressive strength. Also, as the lap splice increases the cracking load increases, in case of the lap splice length lower than thirty times, the bar diameter the lap length has a considerable effect upon the cracking load. When the lap splice length is higher than or equals to forty times the bar diameter the cracking load was constant, (6.0 ton). This means that with respect to the cracking load of HSC beams reinforced with spliced bars having splice length higher or equals to forty times the bar diameter at region of constant moment the splice length is sufficient. As both the area of tension reinforcement and transfer reinforcement at the splice regions increase the cracking load increase. The cracking load of beam having $1.727 \%$ of tension reinforcement and sixty times bar diameter splice length was 1.20 times the cracking load of beam has $0.958 \%$ of tension reinforcement without splices. This is due to the used splice length is higher than the required length, so at the section of maximum bending moment the area of steel becomes doubled that means there is increasing in the elastic stiffness of the beam, see Table 4.

Both the concrete compressive strength and percentage of tension reinforcement have the same effect on the ultimate load as in cracking load. The ultimate load of beam $\mathrm{B}_{1}$ that made from NSC of compressive strength $27.9 \mathrm{MPa}$ was 0.75 times the ultimate load of beam made from HSC of compressive strength 92.1 MPa. This ratio reduces to 0.70 if the percentage of tension reinforcement increases from 0.958 to 1.727 .

Also, increases of splice length increases the ultimate load. The ultimate load of beams reinforced with bars having splices length $10 \Phi$ and $20 \Phi$ were 0.47 and 0.80 times the ultimate load of beam reinforced without splices. The ultimate loads of beams reinforced with bars having splice length equal to or higher than $30 \Phi$ were higher than ultimate load of beam reinforced without splices. The ultimate load of beams reinforced with bars having splices length $30 \Phi, 40 \Phi, 50 \Phi$ and $60 \Phi$ were 1.07, 1.11, 1.13 and 1.20 times the ultimate load of beam reinforced without splices. This means 
that lap splice length of thirty times the bar diameter is sufficient with respect to ultimate load.

Increases transverse reinforcement at the lap splice region also increases the ultimate loads. Decreases the spacing between stirrups means increases the confinement ratio of concrete in both compression zone and around the lap splice. Decreases the spacing between stirrups at lap splice region from $15 \mathrm{~cm}$ to $5 \mathrm{~cm}$ in case of lap splice length $30 \Phi$ increases the ultimate load by about $56.7 \%$. Using lap splice of $30 \Phi$ with transverse reinforcement spacing of $5.0 \mathrm{~cm}$ safes about $11.0 \%$ of the used steel material as well as increases the ultimate load of the beam by about $4.40 \%$ with respect to the beam has lap splice length 60Ф, which recommended in ECCS 203, [9], see Table 4.

Table 4: Test results of tested beams.

\begin{tabular}{|c|c|c|c|l|c|c|c|c|}
\hline Beam & $\mathbf{P}_{\text {cr }}$ & \multicolumn{3}{|c|}{$\begin{array}{c}\text { Ultimate Load } \\
\text { (ton) }\end{array}$} & \multicolumn{2}{c|}{$\begin{array}{c}\text { Bond Strength } \\
\text { MPa }\end{array}$} & \multirow{2}{*}{$\Delta_{\mathbf{1}}$} & $\Delta_{\mathbf{2}}$ \\
\cline { 3 - 7 } No. & $(\mathbf{t})$ & $\mathbf{P 1}$ & $\mathbf{P 2}$ & $\mathbf{P 3}$ & UOJB & Utest & $\%$ & $\%$ \\
\hline $\mathrm{B}_{1}$ & 4.0 & 13.5 & 12.1 & 13.1 & 4.36 & 2.32 & 0.67 & 0.90 \\
\hline $\mathrm{B}_{2}$ & 5.0 & 14.5 & 16.6 & 14.1 & 7.02 & 2.32 & 0.83 & 0.97 \\
\hline $\mathrm{B}_{3}$ & 5.5 & 15.9 & 17.3 & 14.2 & 7.44 & 2.32 & 0.92 & 1.06 \\
\hline $\mathrm{B}_{4}$ & 6.0 & 18.0 & 18.0 & 14.3 & 7.92 & 2.32 & 1.00 & 1.20 \\
\hline $\mathrm{B}_{11}$ & 6.0 & 15.0 & 18.0 & 14.3 & - & - & 1.00 & 1.00 \\
\hline $\mathrm{B}_{12}$ & 4.5 & 7.0 & 18.0 & 14.3 & 10.89 & 5.85 & 0.75 & 0.47 \\
\hline $\mathrm{B}_{13}$ & 5.0 & 12.0 & 18.0 & 14.3 & 9.11 & 5.01 & 0.83 & 0.80 \\
\hline $\mathrm{B}_{14}$ & 5.5 & 16.0 & 18.0 & 14.3 & 8.52 & 3.71 & 0.92 & 1.07 \\
\hline $\mathrm{B}_{15}$ & 6.0 & 16.7 & 18.0 & 14.3 & 8.22 & 2.32 & 1.00 & 1.11 \\
\hline $\mathrm{B}_{16}$ & 6.0 & 17.0 & 18.0 & 14.3 & 8.04 & 2.32 & 1.00 & 1.13 \\
\hline $\mathrm{B}_{19}$ & 6.5 & 18.8 & 18.0 & 14.3 & 10.15 & 2.32 & 1.08 & 1.25 \\
\hline $\mathrm{B}_{20}$ & 6.3 & 18.5 & 18.0 & 14.3 & 9.68 & 23.2 & 1.05 & 1.23 \\
\hline $\mathrm{B}_{24}$ & 5.5 & 12.0 & 16.7 & 10.1 & 7.92 & 2.04 & 0.92 & 0.80 \\
\hline $\mathrm{B}_{25}$ & 7.0 & 18.0 & 20.6 & 19.8 & 7.92 & 2.19 & 1.17 & 1.20 \\
\hline $\mathrm{B}_{26}$ & 7.2 & 19.2 & 21.78 & 23.6 & 7.92 & 2.24 & 1.20 & 1.28 \\
\hline
\end{tabular}

Where:

$\mathrm{P}_{\mathrm{cr}} \quad$ cracking load;

$\mathrm{P}_{1} \quad$ ultimate experimental load;

$\mathrm{P}_{2} \quad$ ultimate load based on shear failure by using Zusty equation, [12];

$\mathrm{P}_{3} \quad$ ultimate load based on flexural failure based on ACI [11];

$\Delta_{1} \quad$ cracking load of tested beam/ cracking load of beam $\mathrm{B}_{11}$;

$\Delta_{2} \quad$ ultimate load of tested beam/ ultimate load of beam $\mathrm{B}_{11}$ and.

$\mathrm{U}_{\text {OJB }}$ the calculated bond strength in $\mathrm{MPa}$, based on Eqn. (1);

$\mathrm{U}_{\text {test }}$ uniform average experimental bond stress $=\frac{d_{b} f_{s}}{4 L}$ in MPa;

$f_{\mathrm{s}}$ the induced tensile stress in tension steel, calculated by using the ultimate experimental Loads. 


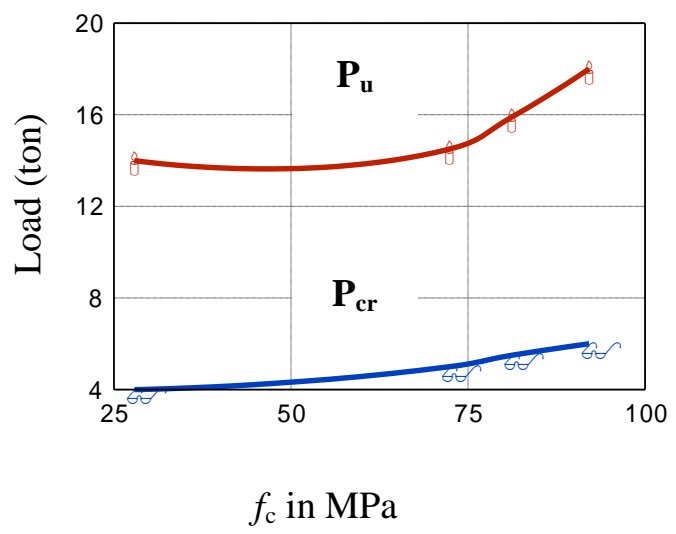

Fig. 3.a: Effect of concretecompressive strength on both cracking and ultimate loads.

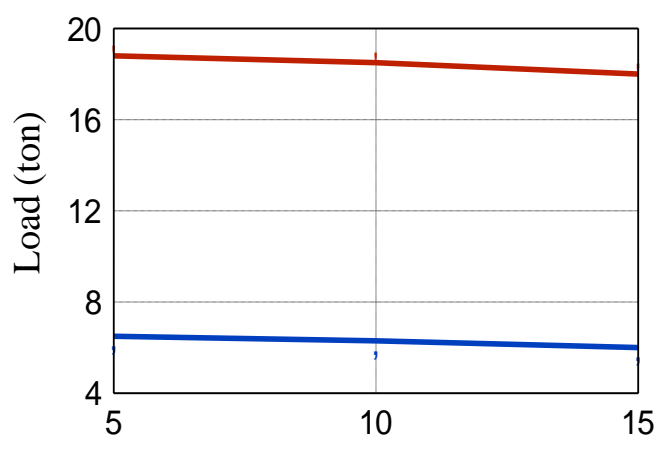

Spacing between stirrups in $\mathrm{cm}$.

Fig. 3.c: Effect of transverse reinforcement at region of lap splice length on cracking and ultimate loads.

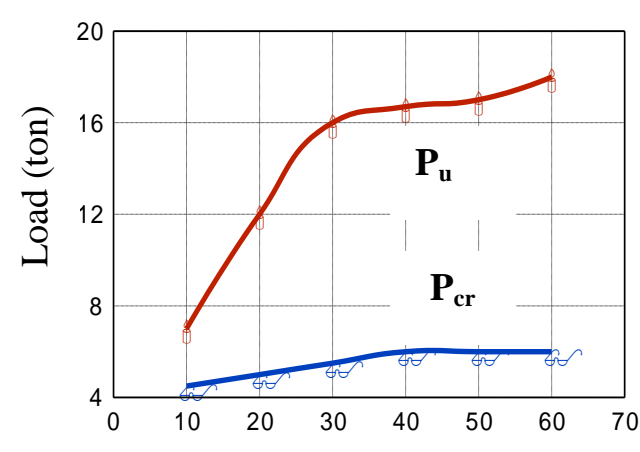

Lap length in times of bar diamter

Fig. 3.b: Effect of lap splice length on cracking and ultimate loads.

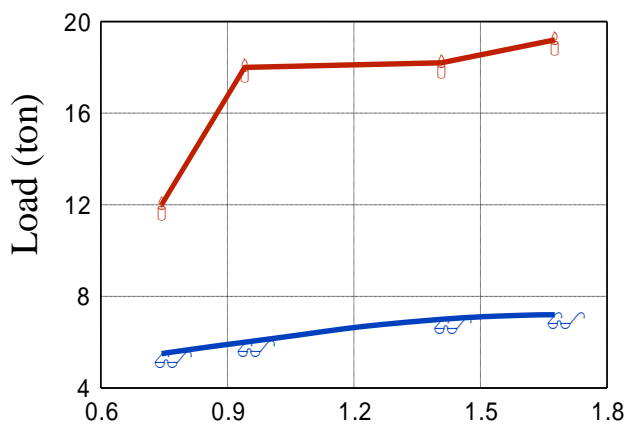

Percentage of tension reinforceemnt

Fig. 3.d: Effect of percentage of tension reinforcement on both cracking and ultimate loads.

\section{BOND STRENGTH}

The average values of bond strengths calculated based on equation (1) that proposed by Organ et-al, [1], are given in Table 5, these values declare that the bond strength is affected by the studied parameters. Considering an evenly distributed bond stress along the spliced length at failure, the bond stress around the bar nominal perimeter was determined directly from the stress developed in the steel bar by equilibrium:

$$
U_{\text {test }}=\frac{d_{b} f_{s}}{4 L}
$$

The values of the experimental average bond stress are calculated by substituting $1.25 f_{\mathrm{y}}$ for $f_{\mathrm{y}}$ to insure ductility as recommended in ACI, [11], for tension splices, these values are also given in Table 5. The bond stress is not the aim of the study but the main aim is the overall behavior of such beams so most of beams splices having bond 
strength capacity calculated by Eqn.(1) higher than the bond stress calculated by using the ultimate experimental loads at failure except beam $B_{12}$ and $B_{13}$ that have short lap splice. The calculated values of bond strength based on Organ et-al [1], showed that decreasing the spacing between transverse reinforcement from $15 \mathrm{~cm}$ to $5 \mathrm{~cm}$ increases the bond strength by about $12 \%$.

Table 5: Test results of tested beams.

\begin{tabular}{|c|c|c|c|c|}
\hline $\begin{array}{c}\text { Beam } \\
\text { No. }\end{array}$ & $\begin{array}{c}\boldsymbol{\delta} \\
\mathbf{( m m})\end{array}$ & $\begin{array}{c}\boldsymbol{\delta}_{\mathbf{f}} \\
(\mathbf{m m})\end{array}$ & $\begin{array}{c}\boldsymbol{\delta}_{\mathbf{e}} \\
(\mathbf{m m})\end{array}$ & $\boldsymbol{\varepsilon}_{\mathbf{s}} \mathbf{\times 1 0 ^ { - 5 }}$ \\
\hline $\mathrm{B}_{1}$ & 17.48 & 6.48 & 4.93 & 167 \\
\hline $\mathrm{B}_{2}$ & 12.33 & 4.90 & 4.20 & 145 \\
\hline $\mathrm{B}_{3}$ & 11.74 & 3.90 & 1.60 & 155 \\
\hline $\mathrm{B}_{4}$ & 17.85 & 1.73 & 1.35 & 172 \\
\hline $\mathrm{B}_{11}$ & 15.64 & - & - & 252 \\
\hline $\mathrm{B}_{12}$ & 5.16 & 4.06 & 2.92 & 65 \\
\hline $\mathrm{B}_{13}$ & 11.42 & 3.90 & 2.68 & 96 \\
\hline $\mathrm{B}_{14}$ & 15.80 & 3.64 & 3.30 & 187 \\
\hline $\mathrm{B}_{15}$ & 16.41 & 2.92 & 11.4 & 159 \\
\hline $\mathrm{B}_{16}$ & 16.58 & 4.59 & 1.0 & 141 \\
\hline $\mathrm{B}_{19}$ & 17.70 & 3.78 & 1.22 & 113 \\
\hline $\mathrm{B}_{20}$ & 16.52 & 3.85 & 2.68 & 181 \\
\hline $\mathrm{B}_{24}$ & 10.00 & 1.60 & 0.89 & 138 \\
\hline $\mathrm{B}_{25}$ & 8.02 & 1.61 & 1.42 & 118 \\
\hline $\mathrm{B}_{26}$ & 8.50 & - & 2.13 & 84 \\
\hline
\end{tabular}

Where:

$\delta \quad$ maximum deflection at ultimate load;

$\varepsilon_{\mathrm{s}} \quad$ maximum steel strain at $75 \%$ of ultimate load;

$\delta_{\mathrm{f}} \quad$ slip at free end; and;

$\delta_{\mathrm{e}} \quad$ slip at embedded end of the splice.

\section{DEFORMATION CHARACTERISTICS}

Figures 4.a to 4.d show the relation between the applied load and the deflection measured at the mid span section for all tested beams. Also, Table 5 presents the values of maximum deflection at ultimate load, steel strain at $75 \%$ of ultimate load as well as free and embeded slip at ultimate load. From investigation of Figures 4.a to 4.d, it is clear that in the first stage of loading the behaviour of the tested beams is slightly affected by the studied variables. In general, increasing of concrete compressive strength, lap splice length, percentage of tension reinforcement and area of transverse reinforcement at lap splice region were accompined with an increment in the stiffness of the tested beams after cracking. As the area of transverse reinforement at lap splice increases both the strength and ductility of the beams was improved.

The maximum deflection at mid span was recorded for beam $\mathrm{B}_{4}$ that has lap splice length $60 \Phi$ and for beam $B_{19}$ that has lap splice length $30 \Phi$ with higher transverse 
reinforcement at lap splice, it is about 1.14 times the maximum deflection of beam $\mathrm{B}_{11}$ that reinforced without splices.

The beams having splice length less than twinty times bar diameter showed no enhancement in the ductility of the tested beams followed by a high reduction in their strengths. In other hand, the beams having splice length higher or equal fourty times the bar daimeter, they usually pocess higher stiffness and ductility.

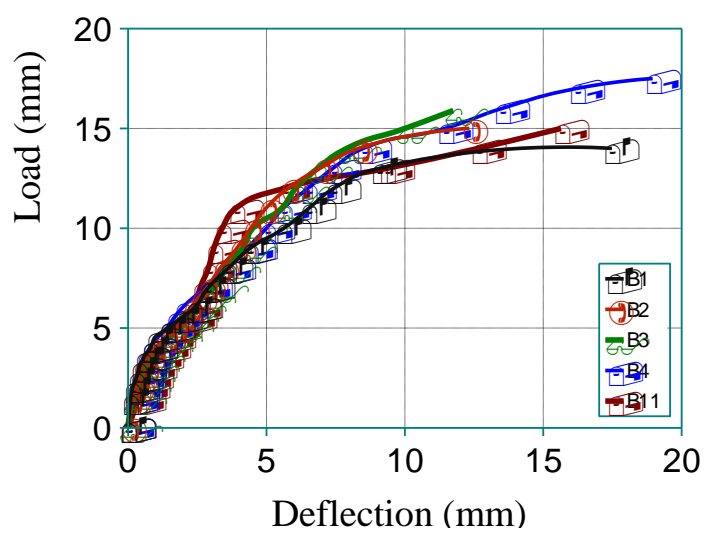

Fig. 4.a: Effect of concrete compressive strength on the deflection of the tested beams.

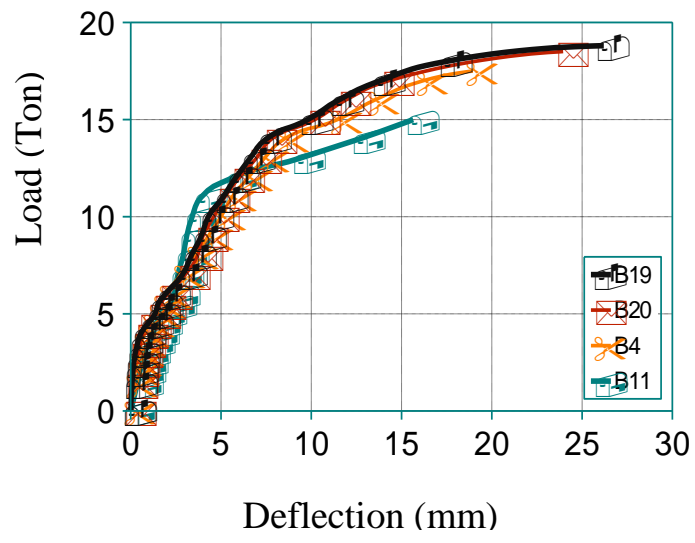

Fig. 4.c: Effect of transverse reinforcement at lap splice region on the deflection of the tested beams.

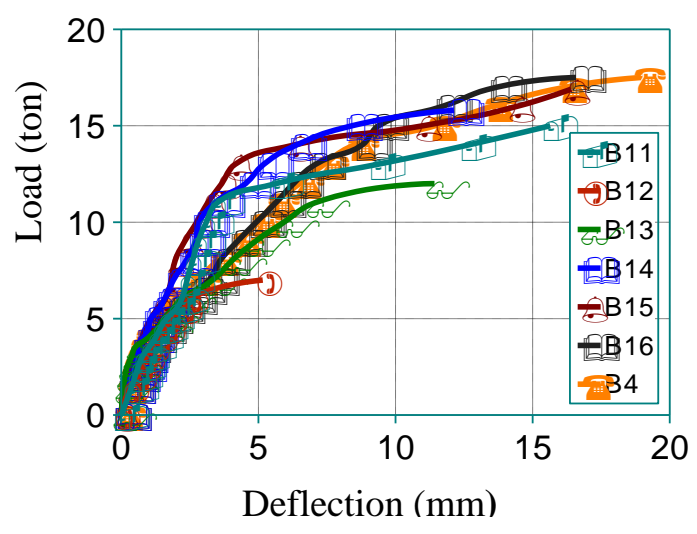

Fig. 4.b: Effect of lap splice length on the deflection of the tested beams.

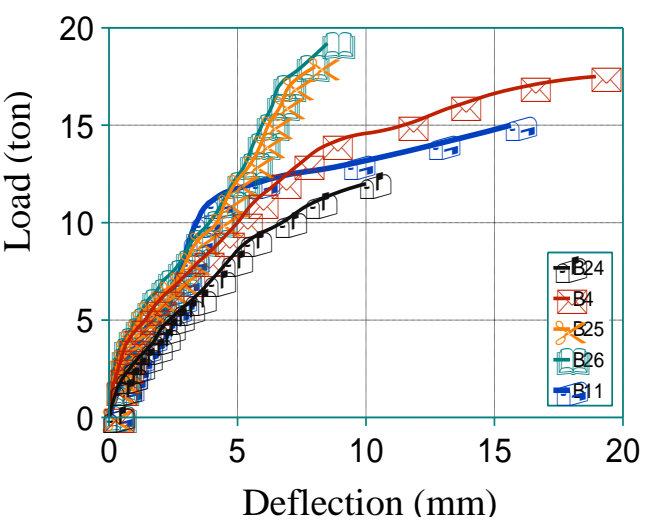

Fig. 4.d: Effect of area of tension Reinforcement on the deflection of the tested beams.

The induced strain on the tension reinforcement at mid span section from the begining of loading up to $75 \%$ from the ultimate load was recorded and plotted on figures 5.a to 5.d. From these curves it is clear that the induced steel strain slightly affected by the compressive strength of the used concrete. Both the percentage of the area of the tension reinforced and lap splice length has a marked effect on the induced steel strain. The induced steel strain was higher in the beam $B_{11}$ that reinforced without splices. If 
the lap splice length was smaller than or equals to twinty time the bar diamter the beam fialed with very small values of induced steel strain. Also, if the splice length is higher than thirty times the bar diameter, the induced steel strain was smaller than that induced in beam $B_{11}$ that reinforced without splices.

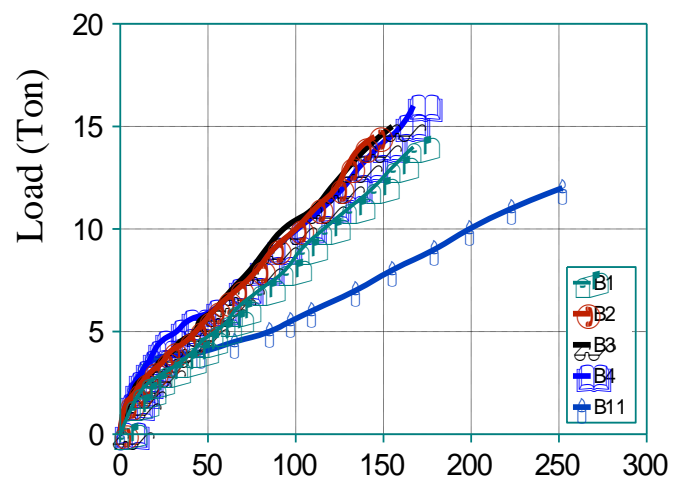

Strain $\times 10^{-5}$

Fig. 5.a: Effect of concrete compressive strength on the induced steel strain.

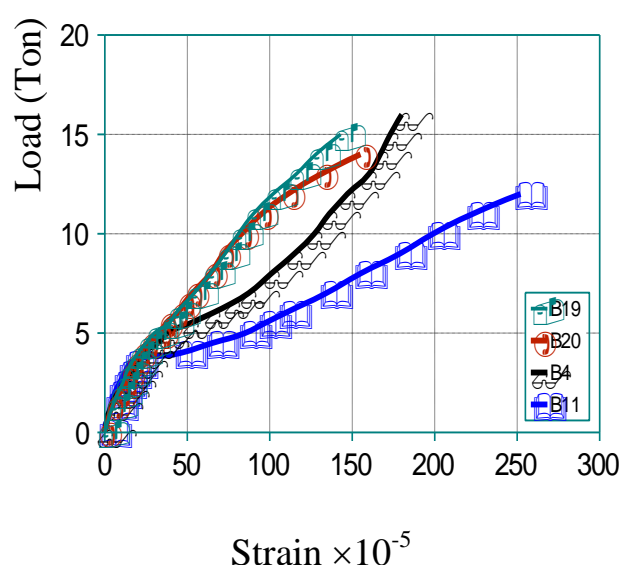

Fig. 5.c: Effect of area of transverse reinforcement on the induced steel strain.

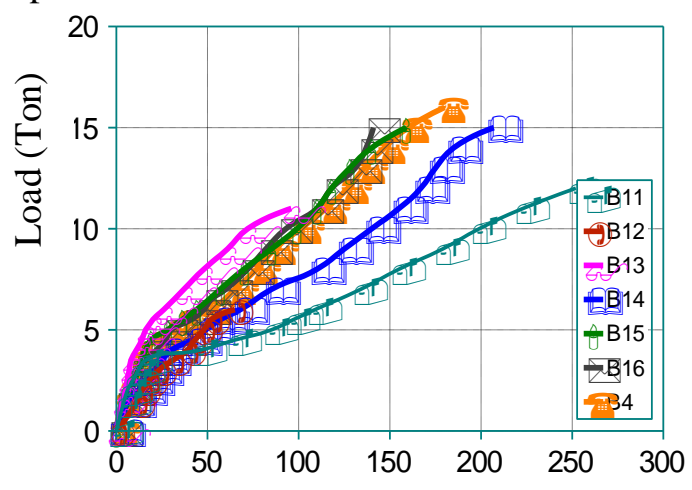

Strain $\times 10^{-5}$

Fig. 5.b: Effect of concrete compressive strength on the induced steel strain.

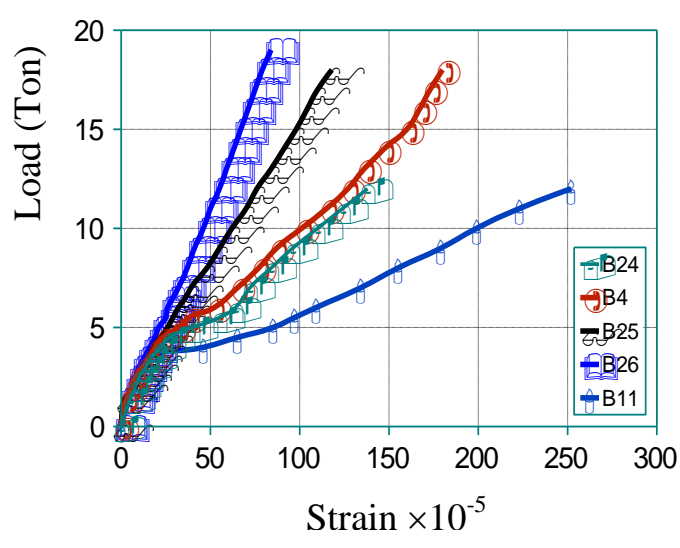

Fig. 5.d: Effect of area percentage of tension reinforcement on the induced steel strain.

This is beacuse the splice length is higher than the required length, so the area of tension steel at mid span setion is doubled, leading to small strain in the tension steel. If the lap splice length was equal to thirty times the bar diameter the induced steel strain was smaller than that the induced strain in beam $B_{11}$ that reinforced without splices, this may be due to the fact that the splice length is sufficient. Increasing of transverse reinforcement at lap splice region usually has no affect on the induced strain 
in the first stage of loading up to cracking load. Beyond cracking load, increasing of transverse reinforcement at lap splice region usually is accompined with decreasing in the induced steel strain.

The slip of the tension reinforcing bras is measured at both the free and embedded end of the bars; its values at failure were given in Table 5. Investigated the values of the slip at both free and embedded ends declares that all studied parameters effects in the slip. The maximum values of the slip in HSC concrete beams is recorded in beam $\mathrm{B}_{12}$ that reinforced with splice length equal to ten times the bar diameter, this means its subjected to high bond stress. The concrete compressive strength has a pronounced effect on the slip, the slip measured in beam made from concrete having 92.1 $\mathrm{MPa}$ compressive strength was about $27 \%$ from the slip from concrete has $27.9 \mathrm{MPa}$ compressive strength.

\section{CONCLUSIONS}

On the light of the available experimental results on HSC beams reinforced with tension bars spliced at maximum bending moment and tested under static loading, the following conclusions and recommendations are drawn:

1- Lap splices of tension reinforcement has a distinguish effect on the overall flexural behavior of HSC tested beams.

2- The concrete compressive strength has a pronounced effect on the cracking load of HSC tested beams and a slight effect on the ultimate load.

3- The lap splice length has also a marked effect on the ultimate load of the tested beams. The ultimate loads of R.C. beams having lap splice length higher than or equal thirty times the bar diameter are higher than those of similar beams reinforced without splices. So with respect to the ultimate load a lap splice length thirty times the bar diameter is enough.

4- Increases of transverse reinforcement at splice region increases the ultimate load of HSC beams. If the splice length equal to thirty times the bar diameter and the confinement ratio at region of lap splice was $1.294 \%$, the ultimate load is higher than the ultimate load of the beam reinforced without splices by $25.3 \%$. Using lap splice length thirty times the bar diameter with transverse reinforcement spacing $5 \mathrm{~cm}$, (confinement ratio at region of lap splice was $1.294 \%$ ), at splice region is safe about $12.71 \%$ of the used steel material at the splice region.

5- Increasing lap splice length for flexural beams usually improves the flexural behavior of such beams particularly an adequate level of ductility for high strength reinforced concrete beams is approved.

\section{REFERENCES}

[1] Orangun, C.O; Jirsa, J. O0; and Breen, J. E.; "Reevaluation of Test Data on Development length and Lap Splices", ACI Journal, No. 3, March 1977, pp. 114122.

[2] Ferguson, P. M., "Small Bar Spacing or Cover- A Bond Problem for the Designer”, ACI Journal, No. 9, Sept. 1977, pp. 435-439. 
[3] Untrauer, R. E; and Warren, G. E.; "Stress Development of Tension Steel in Beams", ACI Journal, No. 8, Aug. 1977, pp. 368-372.

[4] Rezansoff, T.; Akanni, A.; and Sparling, B.; "Confinement Limits for Tension Lap Splices under Static Loading”, ACI Journal, No. 4, July-Aug. 1993, pp. 374384.

[5] Shyh, J., H.; Yih, R. L. and Han, L. H.; "Tensile Bond Strengths of Deformed Bars of High Strength Concrete", ACI Journal, No. 1, Jan.-Feb., 1996, pp. 11-20.

[6] Goto, Yukimasa, "Cracks Formed in Concrete around Deformed Tension Bars", ACI Journal, No. 4, April, 1971, pp. 244-251.

[7] ACI Committee 318, "Building Code Requirements for reinforced concrete and Commentary", American Concrete Institute, Detroit, 1989, pp.353.

[8] Abdel-Hady Hosny, Mohmed I. Soliman and O. Elnaser .; "The Characteristics of Bond Behaviour in the Different National Building Codes", Proceeding of First International conference on Structural Engineering, Ain Shames University, Cairo, Egypt, 16-18 May, 1989.

[9] Egyptian code of Practice for Design and Construction of Concrete Structures ECCS 203-2001.

[10] Wallker P. R. Batayneh M. K. and Regant P. E. "Measured and design of Bond strengths of Deformed Bars, Including the effect of Lateral Compression", Magazine of Concrete Research, No. 1, Feb., 1999, pp. 13-26.

[11] ACI Committee 318, "Building Code Requirements for reinforced concrete and Commentary", American Concrete Institute, Detroit, 1989, pp.353.

[12] Zsutty T., "Shear strength prediction for separate categories of simple beam tests" ACI Journal, No. 2, Feb., Vol. 68, 1971.

[13] Amin E., Sherif Y. and Maher K. T. "Lap splices in Confined Concrete”, ACI Structural Journal, No. 6, Nov.- Dec. 1999, pp. 947-955.

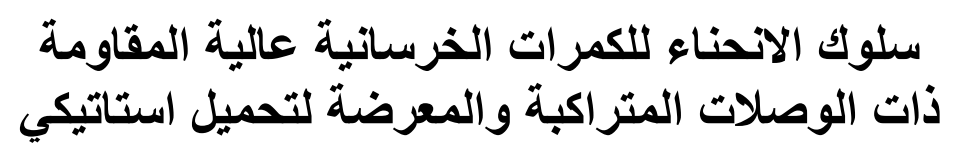

في بعض الأحيان قد بضطر المهندس الإنشائي إلي عمل وصلات بالتر اكب لأسياخ التسليح المشدودة بالانحناء وقد يضطر إلي عمل هذه الوصلات في منطقة أقصي عزم انحناء بسبب طول بحور الكمر ات وبصفة خاصة في الاطار ات و الكباري ذات التئ البحور

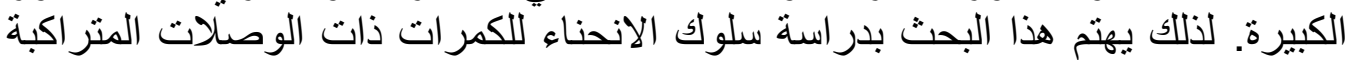
و المصنو عة من خرسانة عالية المقاومة و المعرضة لتحميل استاتيكي.

لهذا الغرض تم إعداد برنامج عملي يتكون من خمسة عشرة كمرة ذات بحر كلي 230 سم وذات قطاع 20×30 سم وتسليح ضغط ثابت 10Ф2 وبحر قص إلي العمق الفعال للكمرة ثابت ويعادل 3.00، منهم وكمرة واحدة ذو مقاومة عادية وذو وصلة متر اكبة، 14 كمرة من خرسانة عالية المقاومة من بينهم كمرة واحدة ذو تسليح شد 
مستمر بدون وصلات و13 كمرة ذو وصلات متر اكبة. وقد تم دراسة العو امل المؤثرة

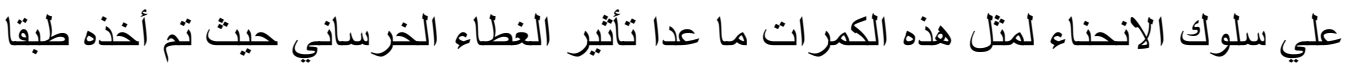
لتوصيات الكود المصري رقم 203 و العو امل التي تم در استها كالأتي: • مقاومة الخرسانة وقد تم أخذها 27.9، 72.4، 81.2، 92.1 ميجابسكال. • طول الوصلة وقد تم أخذها 10، 20، 30، 40، 50، 60 مرة قطر السيخ. ا المسافة بين الكانات في منطقة الوصلة وقد تم أخذها 15سم، 10 سم، 5سم. ه النسبة المئوية لمساحة حديد تسليح الثد وقد تم أخذها 0.756، 0.958، 1.445،

ثم تم اختبار هذه الكمرات تحت تأثير تحميل استاتيكي علي هيئة حملين المسافة بينهما

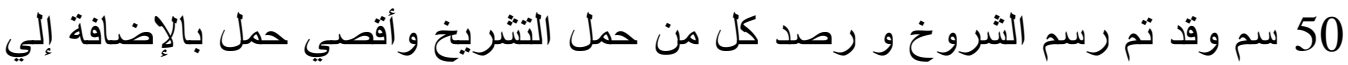

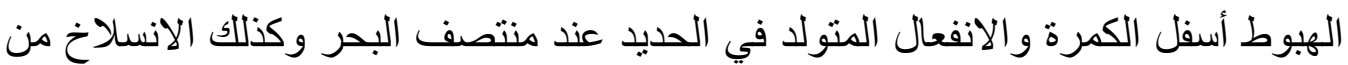

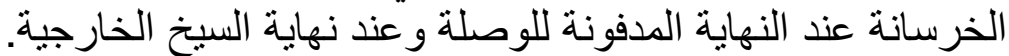

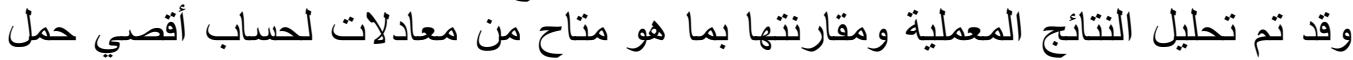

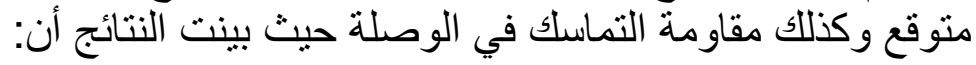

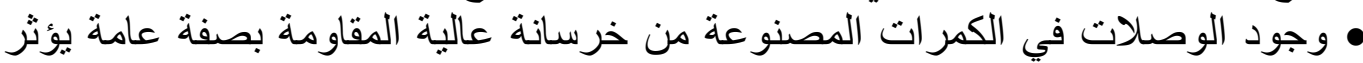

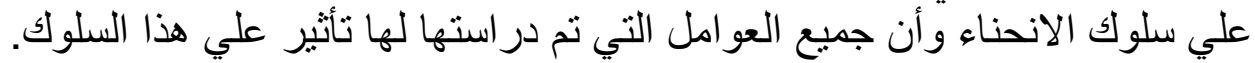

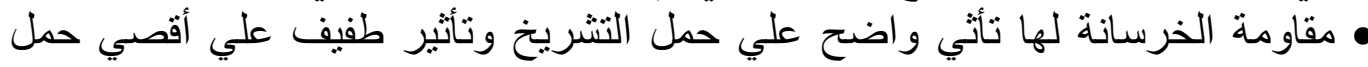
للكمر ات المصنو عة من خرسانة عالية الَّقاومة. • طول الوصلة له تأثثير علي كل من حمل التشريخ وأقدي القهي حمل وأن طول الوصلة أكبر

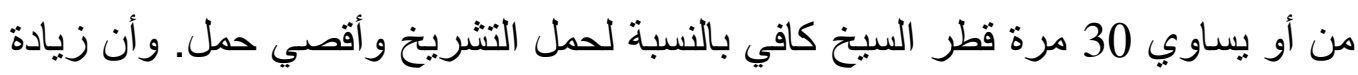
طول الوصلة يحسن من كل من الممطولية و أقصي حمل للكمر ات المختبرة.

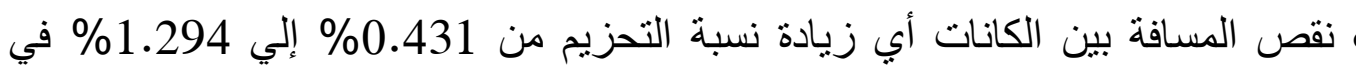
منطقة الوصلة يحسن من ممطولية هذه الكمرات ومن قيم أقصي حمل لها وأن استخدام

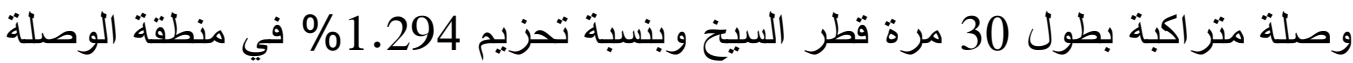
يزيد أقصي حمل للكمرة ذات الوصلة عن الكمرة ذات التسليح المستمر بنسبة 25.3\% ويزيد أقصي هبوط بنسبة 13.2 \% 